\title{
Antioxidant, antimicrobial, toxicity and analgesic properties of ethanol extract of Solena amplexicaulis root
}

\author{
Md Golam Kabir ${ }^{1}$, Md Monsor Rahman ${ }^{1}$, Nazim Uddin Ahmed², Md Fakruddin³, Saiful Islam² \\ and Reaz Mohammad Mazumdar ${ }^{2 *}$
}

\begin{abstract}
Background: This study was subjected to investigate different pharmacological properties of ethanol extract of Solena amplexicaulis root.

Results: The extract contains flavonoid, alkaloid, saponin and steroid compounds. The extract exhibited excellent antioxidant activity in DPPH radical scavenging activity. The extract also showed potent activity in brine shrimp lethality bioassay. The $\mathrm{LC}_{50}$ value was found to $44.677 \mu \mathrm{g} / \mathrm{ml}$. The extract showed better anti-bacterial activity against gram-negative bacteria. In antifungal assay, the maximum $79.31 \%$ of anti-mycotic activity was observed against Aspergillus ochraceus while minimum 44.2\% against Rhizopus oryzae. MIC value ranged between $1500-3000 \mu \mathrm{g} / \mathrm{ml}$. The extract was found moderately toxic with a $24-\mathrm{hr} \mathrm{LD}_{50}$ value of $81.47 \mathrm{mg} / \mathrm{kg}$ in Swiss albino mice. The degree of inhibition by the ethanolic extract of the root was found less than that of standard analgesic drug diclofenac sodium. The extract also showed moderate anti-inflammatory and antinociceptive activity and anti-diabetic property. Reducing power of the extract was comparable with standard ascorbic acid. Moderate in vitro thrombolytic activity, lipid peroxidation inhibition property, metal chelating ability and stress-protective activity was also observed.
\end{abstract}

Conclusion: Ethanol extract of Solena amplexicaulis root can be valuable for treatment of different diseases.

Keywords: Solena amplexicaulis, Antioxidant, Antimicrobial, Acute toxicity

\section{Background}

Plants are capable of synthesizing secondary metabolites [1] which can be used for the new drugs discovery and development. Medicinal plant extracts are potential source for the development of new agents effective against infections currently difficult to treat. Antimicrobial activity of different herbal extracts has been reported against many human pathogens [2-4]. Recently, 546 species have been identified as having medicinal properties and therapeutic use [5]. The medicinal values of those plants possess some chemical active substances that produce a definite physiological action on the human body and animal health. The most important bioactive substances are alkaloid, tannin, flavonoid and phenolic

\footnotetext{
* Correspondence: reazbio@gmail.com

${ }^{2}$ Bangladesh Council of Scientific and Industrial Research (BCSIR) Laboratories Chittagong, Chittagong 4220, Bangladesh

Full list of author information is available at the end of the article
}

compounds [6]. Drugs which are used presently for the management of pain and inflammatory conditions are either steroidal like corticosteroids or non steroidal like aspirin. All of these drugs possess more or less side and toxic effects like renal failure, allergic reactions, hearing loss or they may increase the risk of hemorrhage by affecting platelet function [7]. Solena amplexicaulis is a perennial dioecious climber with tuberous root found throughout Asia mainly growing in hilly dry deciduous forests, scrub jungles. The tubers, leaves and seeds are extensively used in traditional system for various ailments like hepatosplenomegaly, spermatorrhoea, appetizer, cardiotonic, diuretic and thermogenic, haemorrhoids and invigorating [8-10]. The leaves have good anti-inflammatory activity and also prescribed for skin lesions and other skin diseases [11]. The whole plant is determined to be a potential source of natural antioxidant activity $[12,13]$ and also used for the treatment of diabetes 
[14]. It is distributed in China, India, Malaysia, Myanmar, Nepal, Pakistan, and Srilanka. In Bangladesh this species is found in Chittagong, Chittagong Hill Tracts, [15]. Except anti-inflammatory activity [16] antioxidant [12] and antibacterial [17] of Solena amplexicaulis there is no published work on the pharmacological effect of root extracts of the plant. The previous studies were done with leaf and stem or the whole plant. Hence, the present study was considered worthwhile to determine the antioxidant, antimicrobial, cytotoxic, toxic and analgesic properties of crude extract of the root of the plant.

\section{Results}

\section{Phytochemical screening}

Qualitative phytochemical tests of Solena amplexicaulis were performed for the ethanol extract of the root. The results of various chemical tests for the detection and identification of chemical constituents were summarized in Table 1.

\section{Total phenol and flavonoid content and total ascorbic acid content}

The total phenol and total flavonoid contents of Solena amplexicaulis root of ethanol extract were expressed in Gallic acid and Quercetin equivalents respectively. Total phenolic content was $12.36 \mathrm{mg} / \mathrm{g}$ Gallic acid equivalent and total flavonoid content was $18.9 \mathrm{mg} / \mathrm{g}$ Quercetin equivalent. Total ascorbic acid content was found to be $0.357 \mathrm{mg} \mathrm{AA} / \mathrm{g}$.

\section{Antioxidant activity}

The DPPH free radical scavenging activity of Solena amplexicaulis root ethanol extracts, and ascorbic acid is shown in Table 1. Among the eight different concentration used in the study $(10,50,100,200,400,600,800$ and $1000 \mu \mathrm{g} / \mathrm{ml}$ ) ascorbic acid showed 50.78\%, 73.62\%, 84.27\%, 90.13\%, 92.52\%, 94.52\%, 97.06\% and 98.66\% scavenging activity where highest scavenging activity was $98.66 \%$ at concentration $1000 \mu \mathrm{g} / \mathrm{ml}$. On the other hand, Solena amplexicaulis root ethanol extract showed 60.29\%, $62.21 \%$, 64.14\%, 66.79\%, 69.46\%, 72.37\%, 77.60\%, 93.97\% scavenging activity at the aforesaid eight different

Table 1 Result of phytochemical screening of ethanol root extract of $S$. amplexiculis

\begin{tabular}{cccc}
\hline Tests & SAET & Tests & SAET \\
\hline Flavonoid & + & Carbohydrate & + \\
Tannin & - & Resin & + \\
Glycoside & + & Protein & + \\
Alkaloid & + & Saponins & + \\
Anthraruinone & - & Steroids & + \\
\hline
\end{tabular}

(SAET denote for ethanolic extracts of Solena amplexicaulis root; $(+)=$ present; $(-)=$ Absent $)$. concentrations where highest scavenging activity of Solena amplexicaulis root ethanol extracts were 93.97\% $(1000 \mu \mathrm{g} / \mathrm{ml})$. Scavenging activity (\%) or \% of inhibition was plotted against log concentration and from the graph $\mathrm{IC}_{50}$ (Inhibition concentration 50 ) value was calculated by linear regression analysis. $\mathrm{IC}_{50}$ value of ascorbic acid and Solena amplexicaulis root ethanol extracts were 5.46 and 4.18 respectively (Figure 1 ).

\section{Antibacterial activity}

The results of antibacterial activity of the ethanolic root-extract of the plant Solena amplexicaulis are presented in Table 2. In comparison to reference standard tetracycline (30 $\mu \mathrm{g} /$ disc), the ethanolic root-extract exhibited moderate antibacterial activity against selected organisms.

\section{Antifungal activity}

The antifungal effect of the ethanolic root extract of Solena amplexicaulis in various concentrations is presented in Table 3. The strongest antifungal effect was shown by the plant root extract with regard to Aspergillus ochraceus and $A$. niger, as the percent of inhibition was 79.31 \& 62.10 respectively at $5 \mathrm{mg} /$ plate. More weakly expressed was its effect with regard to $A$. ustus.

\section{MIC of the extract}

The MIC value against Gram positive and Gram-negative bacteria ranged from 2,000 to $3,500 \mu \mathrm{g} / \mathrm{ml}$, respectively (Table 4). Lowest MIC value $(1500 \mu \mathrm{g} / \mathrm{ml})$ of SAET was against Bacillus polymyxa, Salmonella typhi, Shigella sonnei and E. coli. MIC value was higher $(3000 \mu \mathrm{g} / \mathrm{ml})$ against Bacillus cereus, Aspergillus niger and Penicillium chrysogenum. MIC value was much higher than control antibiotic, Doxycycline hydrochloride. Considering the impurities and complex composition of the extract, MIC value against the pathogens included in this study was promising.

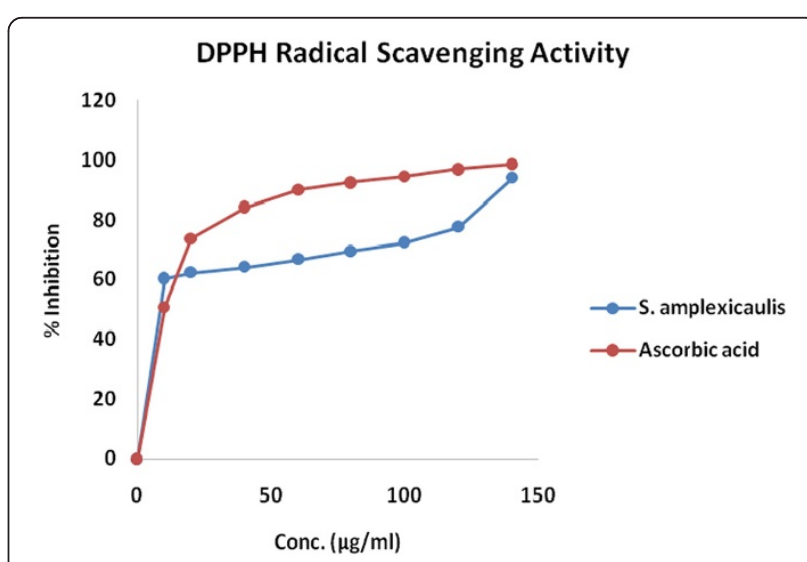

Figure 1 DPPH radical scavenging activity of Solena amplexiculis root extract. 
Table 2 In vitro anti-bacterial effect of ethanolic root-extract of Solena amplexicaulis

\begin{tabular}{|c|c|c|c|c|}
\hline \multirow[t]{3}{*}{ Test organism } & \multirow{3}{*}{$\begin{array}{l}\text { Source ID } \\
\text { (ATCC) }\end{array}$} & \multicolumn{3}{|c|}{ Diameter of zone of inhibition $(\mathrm{mm})$} \\
\hline & & \multicolumn{2}{|c|}{ Ethanolic extract of the root from } & \multirow[t]{2}{*}{ Tetracycline $30 \mu \mathrm{g} / \mathrm{dis}$} \\
\hline & & $2 \mathrm{mg} / \mathrm{disc}$ & $4 \mathrm{mg} / \mathrm{disc}$ & \\
\hline \multicolumn{5}{|l|}{ Gram positive } \\
\hline Bacillus subtilis & 11774 & 7 & 10 & 21 \\
\hline Staphylococcus aureus & 25923 & 7.5 & 10 & 24 \\
\hline Bacillus cereus & 10876 & 7 & 10.5 & 12 \\
\hline B. polymyxa. & 842 & 8.5 & 11.0 & 21 \\
\hline B.megaterium & 13578 & 7 & 11.5 & 28 \\
\hline Enterococcus faecalis & 29212 & 6.5 & 9.5 & 19 \\
\hline \multicolumn{5}{|l|}{ Gram negative } \\
\hline Klebsiella pneumoniae & 65154 & 11.5 & 16.5 & 22 \\
\hline Salmonella typhi & 12022 & 12.0 & 18.5 & 27 \\
\hline Shigella flexneri & 13883 & 10.5 & 14.5 & 15 \\
\hline Shigella sonnei & 8992 & 10 & 14.5 & 14 \\
\hline Proteus vulgaris & 13315 & 11 & 15.5 & 17 \\
\hline E. coli & 25922 & 13.5 & 18 & 19 \\
\hline Vibrio cholerae & 15748 & 12.5 & 22.5 & 26 \\
\hline Pseudomonas aeruginosa & 25853 & 12 & 19.5 & 21 \\
\hline
\end{tabular}

\section{Assay for cytotoxicity}

For the determination of cytotoxicity by Brine shrimp lethality bioassay, seven different concentrations (7.81, $15.63,31.25,62.5,125,250$, and $500 \mu \mathrm{g} / \mathrm{ml}$ ) of the ethanolic extract of Solena amplexicaulis root were used. The ethanolic root extract showed lethality in a dose dependent manner (Figure 2). "BioStat -2007" computer software was used for the calculation of probits for each concentration. Probits obtained by means of Finney method were then plotted against corresponding root-extract log concentration and from the plot $\mathrm{LC}_{50}$ (log concentration 50 ) value was calculated by regression analysis. $\mathrm{LC}_{50}$ value of the root-extract of Solena amplexicaulis was found $44.677 \mu \mathrm{g} / \mathrm{ml}$ with $95 \%$ confidence limit with lower limit 32.354 and upper limit $57.927 \mu \mathrm{g} / \mathrm{ml}$.

Table 3 Antifungal effect of ethanolic extract of the root from Solena amplexicaulis

\begin{tabular}{lccccc}
\hline Organism & Source & ID & \multicolumn{3}{c}{ \% inhibition } \\
\cline { 4 - 6 } & & & $\begin{array}{l}\text { SAET } \\
\mathbf{( 3 ~} \mathbf{~ m g )}\end{array}$ & $\begin{array}{l}\text { SAET } \\
\mathbf{( 5 ~} \mathbf{~ m g )}\end{array}$ & $\begin{array}{l}\text { Fluconazole } \\
\mathbf{( 1 0 0} \mathbf{~} \mathbf{g})\end{array}$ \\
\hline Aspergillus ustus & DSM & 63535 & 16 & 52 & 45 \\
Aspergillus niger & DSM & 737 & 47.37 & 62.10 & 65 \\
Aspergillus ochraceus & DSM & 824 & 34.48 & 79.31 & 41 \\
$\begin{array}{l}\text { Penicillium } \\
\text { chrysogenum }\end{array}$ & DSM & 1075 & 23.58 & 45.6 & 48 \\
Rhizopus oryzae & & & & & 46 \\
\hline
\end{tabular}

\section{Acute toxicity}

Based on the mortality data 24 hours after the treatment, the $\mathrm{LD}_{50}$ value of the test substance for mice was found $81.54 \mathrm{mg} / \mathrm{kg}$ bodyweight with the confidence limit of $59.13-101.98 \mathrm{mg} / \mathrm{kg}$ bodyweight at $5 \%$ level of significance. The regression line equation was found as $\mathrm{Y}=-7.1289+6.3633^{*} \log _{10}$ (Dose) where $\mathrm{Y}$ was the probit mortality of the experimental mice (Table 5). Figure 3 shows acute toxicity pattern of SAET with regard to increasing concentration.

\section{Analgesic action}

Acetic acid induced writhing response model were used for the assay of analgesic activity of Solena amplexicaulis roots ethanol extract. After injecting of $1 \%$ ( v/v) acetic acid solution $(3.3 \mathrm{ml} / \mathrm{kg}$ body weight) intra-peritoneally in mice, the control animal showed 82 writhing count/20 minutes but, administration of diclofenac sodium resulted in significant reduction of writhing count, from 82 to 39.5. On the other hand, ethanolic extract of the root from Solena amplexicaulis abridged the writhing count, from 82 to $60.5,70$, and 79.5 at the dose of $35 \mathrm{mg} / \mathrm{kg}$ bodyweight of mice, $25 \mathrm{mg} / \mathrm{kg}$ bodyweight of mice, and $15 \mathrm{mg} / \mathrm{kg}$ bodyweight of mice respectively (Table 6). The effect of the root extract and diclofenac sodium was statistically analyzed by Student's t test. The treatment of animal with the root extract $(35 \mathrm{mg} / \mathrm{kg}, 25 \mathrm{mg} / \mathrm{kg}$, and $15 \mathrm{mg} / \mathrm{kg}$ ) and diclofenac sodium was found significant $(\mathrm{P}<0.001)$ as compared to control group. The degree of 


\begin{tabular}{|c|c|c|c|}
\hline \multirow[t]{2}{*}{ Test organism } & \multirow{2}{*}{$\begin{array}{l}\text { Source ID } \\
\text { (ATCC) }\end{array}$} & \multicolumn{2}{|c|}{ MIC value $(\mu \mathrm{g} / \mathrm{ml})$} \\
\hline & & SAET & $\begin{array}{l}\text { Doxycycline } \\
\text { hydrochloride }\end{array}$ \\
\hline \multicolumn{4}{|l|}{ Gram positive } \\
\hline Bacillus subtilis & 11774 & 2500 & 5.0 \\
\hline Staphylococcus aureus & 25923 & 2000 & 5.5 \\
\hline Bacillus cereus & 10876 & 3000 & 4.5 \\
\hline B. polymyxa. & 842 & 1500 & 6.0 \\
\hline B.megaterium & 13578 & 2000 & 5.5 \\
\hline Enterococcus faecalis & 29212 & 2500 & 4.5 \\
\hline \multicolumn{4}{|l|}{ Gram Negative } \\
\hline Klebsiella pneumoniae & 65154 & 2000 & 5.5 \\
\hline Salmonella typhi & 12022 & 1500 & 6.0 \\
\hline Shigella flexneri & 13883 & 2000 & 6.5 \\
\hline Shigella sonnei & 8992 & 1500 & 5.5 \\
\hline Proteus vulgaris & 13315 & 2500 & 4.5 \\
\hline E. coli & 25922 & 1500 & 5.0 \\
\hline Vibrio cholerae & 15748 & 2500 & 5.0 \\
\hline Pseudomonas aeruginosa & 25853 & 2000 & 4.5 \\
\hline Fungi & & & Fluconazole $(100 \mu \mathrm{g})$ \\
\hline Aspergill usustus & DSM 63535 & 2500 & 7.5 \\
\hline A. niger & DSM 737 & 3000 & 7.0 \\
\hline A. ochraceus & DSM 824 & 2500 & 8.0 \\
\hline Penicillium chrysogenum & DSM 1075 & 3000 & 6.5 \\
\hline Rhizopus oryzae & DSM 2200 & 2500 & 6.0 \\
\hline
\end{tabular}

inhibition of Solena amplexicaulis roots extract (26.22\%, $14.63 \%$, and $3.05 \%$ ) was found less than that of diclofenac sodium (51.83\%) (Figure 4).

\section{Anti-inflammatory activity}

Solena amplexicaulis produced a potent anti-inflammatory activity against the paw edema in Swiss albino rats when compared with reference standards the potency was found to be inversely proportional to the time (Table 7) taken for reduction in the paw volume.

\section{Antinociceptive activity}

The extract produced significant writhing inhibition comparable to the standard drug diclofenac sodium (Figure 5). The results of the test showed that SAET $500 \mathrm{mg} / \mathrm{kg}$ exhibit highly significant $(\mathrm{P}<0.001)$ inhibition of writhing reflex by $6.7 \%$ while the standard drug diclofenac inhibition was found to be $5.6 \%$ at a dose of $25 \mathrm{mg} / \mathrm{kg}$ body weight. Results suggest that ethanolic root extract of $S$. amplexicaulis might possess antinociceptive activity.

\section{a-Amylase inhibitory property}

In an array to explore the anti-diabetic activity, ethanolic root extract of Solena amplexicaulis was screened for the $\alpha$-amylase inhibitory property. Ethanol extracthas significantly higher percentage of $\alpha$-amylase inhibition, that is, $41.3 \%$ and $62.58 \%$ at 25 and $50 \mu \mathrm{g} / \mathrm{mL}$, respectively, while for acarbose of same concentration, the value was $33.25 \%$ and $49.57 \%$.

\section{Reducing power}

The reducing power of the extracts was moderately strong while increasing dose it shows little increment. At $100 \mu \mathrm{g} / \mathrm{ml}$ concentration, reducing power of SAET was 0.24 whereas that of ascorbic acid was 0.26 . But, with increasing concentration $(200-400 \mu \mathrm{g} / \mathrm{ml})$, reducing power of SAET increased from 0.36 to 0.48 whereas that of ascorbic acid increased from 0.38 to 0.53 (Figure 6).

\section{In vitro thrombolytic activity}

Streptokinase (SK) (positive control) showed $68.57 \pm 1.67 \%$ clot lysis while sterile distilled water (negative control) showed only negligible clot lysis $(7.68 \pm 0.578 \%)$. The mean difference in clot lysis percentage between positive and negative control was very significant ( $p$ value $<0.0001$ ). Ethanolic root extract of $S$. amplexicaulis showed $48.51 \pm$ $1.25 \%$ clot lysis and S. amplexiculis in combination with Streptokinase showed $74.29 \pm 0.79 \%$ clot lysis activity. Percent clot lysis obtained after treating clots with herb and appropriate controls is shown in Figure 7.

\section{Lipid peroxidation inhibition assay}

The lipid peroxides scavenging activity of SAET was investigated and compared with standard (Salymarin). At a concentration of $250 \mu \mathrm{g} / \mathrm{ml}$, the \% inhibition was $62.89 \%$ and at $500 \mu \mathrm{g} / \mathrm{ml}$, the \%inhibition was $783.84 \%$ while inhibition of $\mathrm{CCl}_{4}$ and Salymarin was $49.95 \%$ and 92.77\% respectively (Figure 8 ).

\section{Metal chelating effect}

The chelating effect on the ferrous ions by ethanolic root extract of S. amplexicaulis is presented in Table 8. The extracts exhibited the ability to chelate metal ions. Metal chelating activity of SAET at $1000 \mu \mathrm{g} / \mathrm{ml}$ concentration was $29.35 \pm 0.65$ compared to $53.62 \pm 0.25$ of standard EDTA of Same Concentration. At $5000 \mu \mathrm{g} / \mathrm{ml}$ concentration, \% inhibition of SAET was $41.65 \pm 0.44$ whereas that of standard EDTA was $94.67 \pm 0.18$.

\section{Spot assay}

The growth of yeast cells with prior exposure to $\mathrm{H}_{2} \mathrm{O}_{2}$ (2 $\mathrm{mM})$ in presence and absence of SAET showed significant growth difference and extract treated cells grow normally in presence of stress compounds compared to growth of control cells. This shows that the protective 


\section{Brine Shrimp Cytotoxicity of SAET}

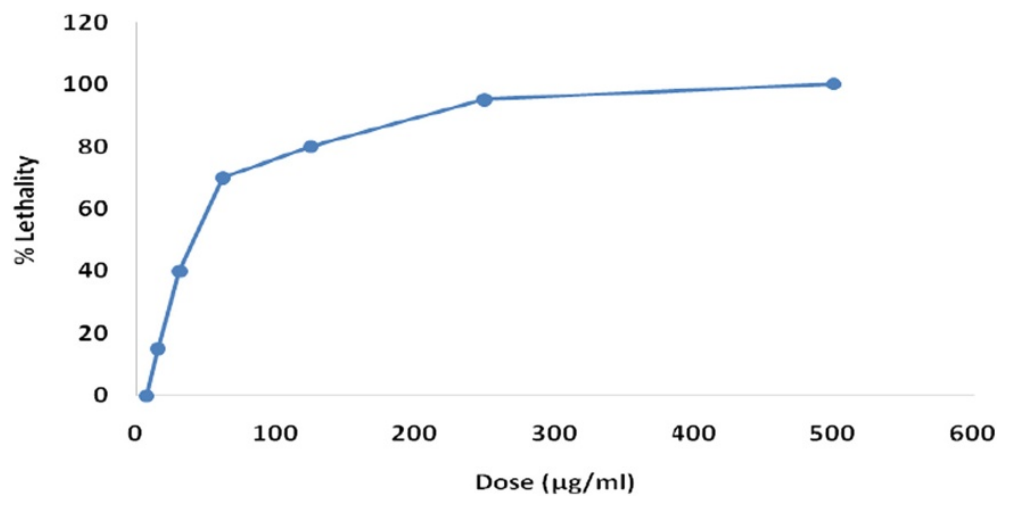

Figure 2 Cytotoxicity of S. amplesiculis root ethanol extract (SAET).

effect of SAET may be attributed to the presence of various anti-oxidant compounds Table 9.

\section{Discussion}

Plants produce a lot of secondary compounds as natural protection against microbial and insect attack. Some of these compounds are toxic to animals, but others may not be toxic. Indeed, many of these compounds have been used in the form of whole plants or plant extracts for food or medical applications in human [18] because plants are the natural reservoir of many antimicrobial, anticancer agents, analgesics, anti-diarrheal, antifungal as well as various therapeutic activities [19]. The total phenol of Solena amplexiculis of ethanol extract were $12.36 \mathrm{mg} / \mathrm{g}$ Gallic acid equivalent and total flavonoid content was $18.9 \mathrm{mg} / \mathrm{g}$ Quercetin equivalent. Total ascorbic acid content was found to be $0.357 \mathrm{mg} \mathrm{AA} / \mathrm{g}$. Acceptance of medicines from such plant origin as an alternative form of healthcare is increasing because they are serving as promising sources of novel antibiotic prototypes [20]. Some of the phytochemical compounds e.g. glycoside, saponin, tannin, flavonoids, terpenoid, alkaloids, have variously been reported to have antimicrobial activity [18].

Free radicals from oxidative stress are involved in many disorders like atherosclerosis, angina pectoris, neurodegenerative diseases and cancer. Antioxidants due to their scavenging activity are useful for the management of those diseases. DPPH assay is one of the most widely used methods for screening antioxidant activity of plant extracts. The quantitative determination of antioxidants explored that high quantity of scavenging substances are found to be [21] in Solena amplexicaulis which plays the key role in showing free radical scavenging activity of this plant. Solena amplexicaulis root exhibited significant $\mathrm{DPPH}$ free radical scavenging activity with $\mathrm{IC}_{50}$ value of $4.18 \mu \mathrm{g} / \mathrm{ml}$. Reducing power of Solena amplexicaulis is also moderately strong. Venkateshwarlu et al. [12] reported the presence of phenolic (gallic acid content is $63.63 \mu \mathrm{g} / \mathrm{mg}$, respectively), and flavonoid compounds (41.18 $\mu \mathrm{g} / \mathrm{mg})$ present in Solena amplexicaulis. The phenolic compounds may contribute directly to the antioxidative action [22]. The results obtained in the present study indicate that the SAET is a potential source of natural antioxidant activity which is in accordance with the study of Venkateshwarlu et al. [12].

Crude extract at the concentration of $1 \mathrm{mg} /$ disc showed 7, 7.5 and $7 \mathrm{~mm}$ zone of inhibition diameter against Gram-positive Bacillus subtilis, Bacillus cereus, and Bacillus megaterium, respectively and $7 \mathrm{~mm}$ diameter against Gram-negative Shigella sonnei. On the other hand, standard antibiotic Tetracycline $(30 \mu \mathrm{g} /$ disc $)$ showed significant antibacterial activity against all tested gram positive and Gram-negative bacteria except proteus vulgaris. Results implicated that the Gram-positive bacteria were more sensitive to the extract than the gram-negative bacteria. Bacillus spp. were the most susceptible bacteria in this study. In a previous study, ethanolic stem bark extract of Clausena heptaphylla showed 5.5, 5.9 and $6.4 \mathrm{~mm}$ zone of inhibition diameter at the concentration of $2 \mathrm{mg} /$ disc against Gram-positive Bacillus subtilis, Bacillus cereus and Bacillus megaterium, respectively and 3.1, 2.5, 1.8, $3.6 \mathrm{~mm}$ diameter against Gram-negative Salmonella typhi, Shigella flexneri, Proteus

Table 5 Calculation of LD $_{50}$ value, regression equation and confidence limit by probit analysis

\begin{tabular}{|c|c|c|c|c|c|}
\hline \multirow{2}{*}{$\begin{array}{l}\log _{10} \\
L_{50}\end{array}$} & \multirow{2}{*}{$\begin{array}{l}\mathrm{LD}_{50} \\
(\mathrm{mg} / \mathrm{kg})\end{array}$} & \multirow{2}{*}{$\begin{array}{l}\text { 95\% confidence } \\
\text { limit }(\mathrm{mg} / \mathrm{kg})\end{array}$} & \multirow{2}{*}{$\begin{array}{l}\text { Regression } \\
\text { equation }\end{array}$} & \multicolumn{2}{|c|}{ Chi-square value } \\
\hline & & & & Calculated & Tabulated \\
\hline 1.91 & 81.54 & 59.13-101.98 & $Y=-7.129+6.363^{*} X$ & 8.24 & 9.49 \\
\hline
\end{tabular}

Here, $\mathrm{Y}$ and $\mathrm{X}$ indicate probit and $\log _{10}$ (Dose) respectively , * mean multiplication. 


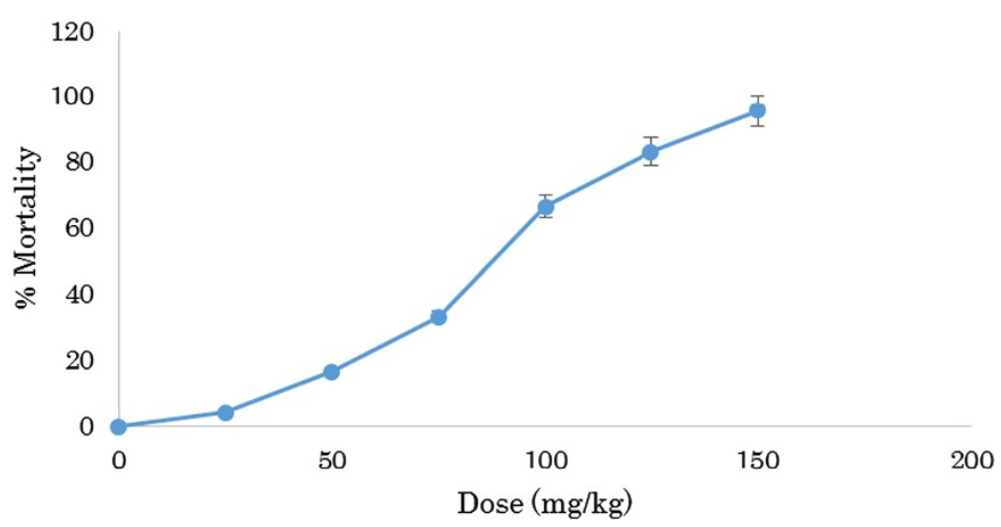

Figure 3 Acute toxicity of SAET.

vulgaris and E. coli. [23]. Stem bark extract showed significant zone of inhibition against Aspergillus ustus, Aspergillus niger and Aspergillus ochraceus in antifungal assay. Solena amplexicaulis showed zone of inhibition to almost all the strains (at dose 3 and $5 \mathrm{mg} /$ disc). Solena amplexicaulis has almost similar activity as Clausena heptaphylla in this study [24]. The present study justifies the claimed uses of Solena amplexicaulis in the traditional system of medicine to treat various infectious diseases caused by the microbes. Solena amplexicaulis showed a significant degree of anti-fungal activity (Table 3). The maximum anti-mycotic activity $79.31 \%$ was shown against A. ochraceus. Plant natural compounds are important source of mycotoxic compounds and they may provide a renewable source of useful fungicides that can be utilized in anti-mycotic drugs against infection of $A$. ochraceus. The effect of extract against $A$. niger was also higher implying that this plant can be utilized as anti-mycotic drugs against infection of $A$. niger in patients with pulmonary tuberculosis [24]. Moderate anti-mycotic effect was found against Aspergillus ustus at the concentration of 3 and $5 \mathrm{mg} / \mathrm{ml}$. Fluconazole was used as standard antifungal agent to compare the potentials of extract. There are, however, alarming reports of opportunistic fungal infections which describe that the resistance of the organisms increased due to indiscriminate use of commercial anti-microbial drugs commonly used for the treatment of infectious disease. This situation forced the researchers to search for new anti-microbial substance from various sources including medicinal plant [24].
Karthika and Paulsamy [17] reported that S. Amplexicaulis extracts of leaf and stem exhibited antibacterial and anti-fungal activity. The findings revealed that medicinal plant Solena amplexicaulis can play a vital role in combating fungal resistance.

Lowest MIC value $(1500 \mu \mathrm{g} / \mathrm{ml})$ against B. polymyxa, Salmonella typhi, Shigella sonnei and E. coli was showed by the extract. Lowest MIC value $(2500 \mu \mathrm{g} / \mathrm{ml})$ was found against fungi such as Aspergillus ustus, A. ochraceus and Rhizopus oryzae. MIC value of the extract against the test pathogens are much higher than that of Doxycycline hydrochloride which may be due to the crude nature of the pigment extracts. Natural compounds from plants are important source of mycotoxic compounds and they can be a source of useful fungicides that can be utilized in anti-mycotic drugs against infection of $A$. ochraceus [24].

Different pharmacological properties can be assumed on the basis of brine shrimp cytotoxicity of any plant extract [23]. In this research, six different concentrations $(7.81,15.62,31.25,62.5,125,250,500 \mu \mathrm{g} / \mathrm{ml})$ of Solena amplexicaulis extract were used to determine its cytotoxicity by brine shrimp lethality bioassay. The extract showed lethality in a dose dependent manner. $\mathrm{LC}_{50}$ value of Solena amplexicaulis ethanol extract was found $44.68 \mu \mathrm{g} / \mathrm{ml}$ (Figure 2). The $\mathrm{LC}_{50}$ value found in this study was very significant suggesting the ethanol extract of Solena amplexicaulis has high potentiality to kill cancer cells as well as pests [25]. This significant lethality of the crude plant extract (as $\mathrm{LC}_{50}$ value less than $100 \mu \mathrm{g} / \mathrm{ml}$ ) to brine shrimp is indicative of

Table 6 acetic acid induced writhing response of the plant root extract in mice

\begin{tabular}{|c|c|c|c|c|c|}
\hline \multirow{3}{*}{$\begin{array}{l}\text { Writhing count/ } \\
20 \text { minutes }\end{array}$} & \multirow[t]{2}{*}{ Control } & \multirow{2}{*}{$\begin{array}{l}\text { Diclofenac sodium } \\
\text { (40 mg/kg) }\end{array}$} & \multicolumn{3}{|c|}{ Solena amplexicaulis } \\
\hline & & & $\begin{array}{c}35 \mathrm{mg} / \mathrm{kg} \\
\text { bodyweight }\end{array}$ & $\begin{array}{c}25 \mathrm{mg} / \mathrm{kg} \\
\text { bodyweight }\end{array}$ & $\begin{array}{c}15 \mathrm{mg} / \mathrm{kg} \\
\text { bodyweight }\end{array}$ \\
\hline & $82 \pm 1.52$ & $39.5 \pm 1.34^{* *}$ & $60.5 \pm 1.48^{* *}$ & $70 \pm 1.21^{* *}$ & $79.5 \pm 1.02^{* *}$ \\
\hline
\end{tabular}

** $p<0.001$, Here, All the value are expressed as Mean \pm SEM. 


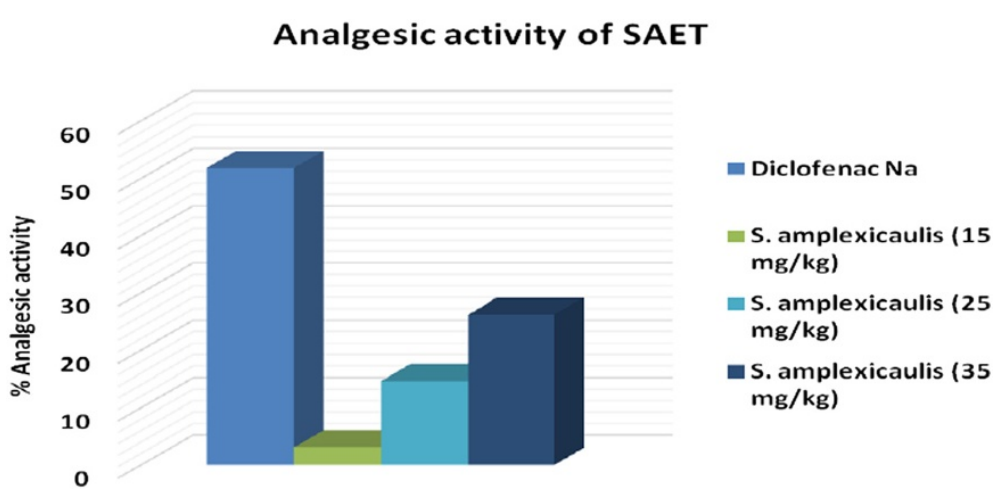

Figure 4 Effect of ethanolic root-extract of Solena amplexicaulis on acetic acid induced writhing response mice model.

the presence of potent cytotoxic compounds which warrants further investigation.

From the study, it was observed that the watersoluble absolute ethanolic extract of the root of Solena amplexicaulis (Gandhi) exhibited toxic properties to the experimental animals (Swiss albino mice). The extract showed its acute toxicity on mice when administered orally in the range of 50 to $150 \mathrm{mg} / \mathrm{kg}$ bodyweight of mice. The 24-hr $\mathrm{LD}_{50}$ values were found to be $81.54 \mathrm{mg} / \mathrm{kg}$ bodyweight of mice. However, it caused no mortality in the treated mice and rats when they were treated orally at the doses of $25 \mathrm{mg} / \mathrm{kg}$ and $75 \mathrm{mg} / \mathrm{kg}$ bodyweight respectably, though some physiological changes occurred. It might have the properties of muscarinic activity and respiratory analeptics on mice and rats. It might also cause visceral changes in mice as well as possess central depressant property to a variable extent on mice. Thus, the study presented here indicates the antinociceptive action of the ethanolic root extract in the acetic acid writhing test could be due to the inhibition of the release of TNF- $\alpha$, interleukin- $1 \beta$ and interleukin- 8 [26] by resident peritoneal cells. The root extract of the plant showed significant inhibition $(\mathrm{P}<0.001)$ of acetic acid induced writhing response of mice. So it can be suggested that Solena amplexicaulis root extract has potential analgesic action [27].

In the present study, pre-treated oral administration of extract was effective in reducing the oedematogenic response evoked by carrageenan in rats between the 2nd and 4th hours after the injection. This evidence allows us to suggest that anti-inflammatory actions of the extract are related to the inhibition of one or more intracellular signaling pathways involved in the effects of several inflammatory mediators. Anti-inflammatory activity increased with the increase in the dose of the extract. Significant anti-inflammatory activity of SAET also corresponds to the presence of flavonoid compounds in the extract as flavonoids are considered to possess anti-inflammatory activity [28].

SAET showed significant antinociceptive activity compared to diclofenac sodium. Acetic acid-induced writhing model represents pain sensation by triggering localized inflammatory response. Acetic acid, which is used to induce writhing, causes algesia by liberation

Table 7 Anti-inflammatory activity of SAET

\begin{tabular}{|c|c|c|c|c|c|}
\hline \multirow[t]{2}{*}{ Groups } & \multirow{2}{*}{$\begin{array}{l}\text { Dose of extract } \\
(\mathrm{mg} / \mathrm{kg}) \text { p.o. }\end{array}$} & \multicolumn{4}{|c|}{ Change in paw thickness $(\mathrm{mm}) \pm \mathrm{SD}(\%$ inhibition) } \\
\hline & & 1 hour & 2 hour & 3 hour & 4 hour \\
\hline Carrageenan control & & $1.34 \pm 0.1$ & $2.3 \pm 0.118$ & $3.64 \pm 0.147$ & $3.23 \pm 0.161$ \\
\hline \multicolumn{6}{|l|}{$(.01 \mathrm{ml}$ of $1 \% \mathrm{w} / \mathrm{v})$} \\
\hline Carrageenan & 200 & $1.14 \pm 0.103(14.93 \%)$ & $1.74 \pm 0.217(26.44 \%) \mathrm{a}$ & $2.50 \pm 0.106(31.3 \%) \mathrm{a}$ & $1.97 \pm 0.115$ (39.0\%)a \\
\hline \multicolumn{6}{|l|}{$\begin{array}{c}(0.1 \mathrm{ml} \text { of } 1 \% \mathrm{w} / \mathrm{v})+\text { aqueous } \\
\text { extract }\end{array}$} \\
\hline Carrageenan & 400 & $1.00 \pm 0.12(25.6 \%)$ & $1.54 \pm 0.163(35.02 \%) \mathrm{a}$ & $1.81 \pm 0.009$ (50.09\%)a & $1.41 \pm 0.188(56.34 \%) a$ \\
\hline \multicolumn{6}{|l|}{$\begin{array}{c}(0.1 \mathrm{ml} \text { of } 1 \% \mathrm{w} / \mathrm{v})+\text { aqueous } \\
\text { extract }\end{array}$} \\
\hline Carrageenan & 10 & $0.59 \pm 0.118(55.97 \%) \mathrm{a}$ & $0.8 \pm 0.121(66.24 \%) a$ & $1.14 \pm 0.121(68.82 \%) a$ & $0.9 \pm 0.118(72.13 \%) a$ \\
\hline $\begin{array}{c}(0.1 \mathrm{ml} \text { of } 1 \% \mathrm{w} / \mathrm{v})+\text { diclofenac } \\
\text { sodium }\end{array}$ & & & & & \\
\hline
\end{tabular}




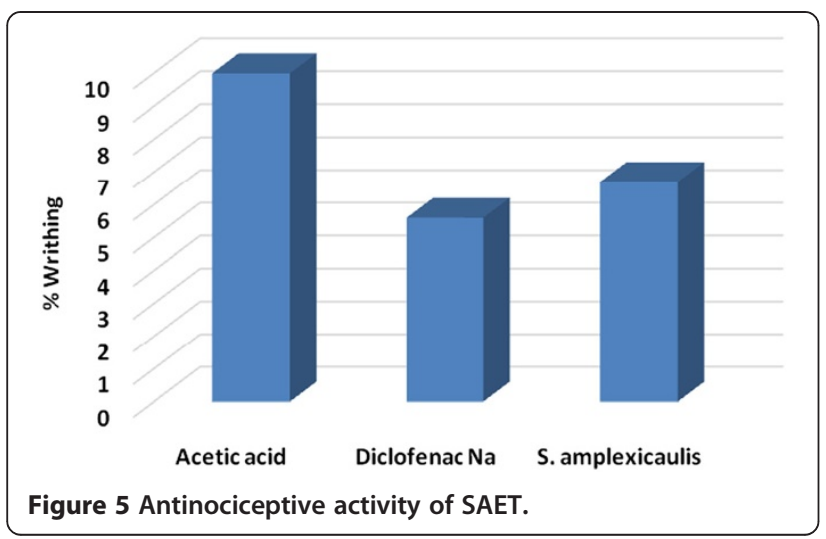

of endogenous substances, which in turn excitethe pain nerve endings [29] localized inflammatory response.

Leaf and stem extracts of $S$. amplexicaulis has been reported to possess anti-diabetic activity in terms of their $\alpha$-amylase inhibition activity [30,31]. Ethanolic root extract also showed better anti- $\alpha$-amylase property $(62.58 \%$ at $50 \mu \mathrm{g} / \mathrm{mL})$ than standard drug acarbose $(49.57 \%$ at $50 \mu \mathrm{g} / \mathrm{mL}$ ). This enzyme inhibitory activity of SAET may be attributed to presence of different active compounds such as flavonoids, glycosides and polyphenols.

In the present study, the reducing power of the SAET was evaluated measuring the conversion of a $\mathrm{Fe}^{3+}$ ferricyanide complex to the ferrous form. The reducing power of the investigated extract linearly increased with concentration. At $100 \mu \mathrm{g} / \mathrm{ml}$ concentration, reducing power of SAET was 0.24 whereas that of ascorbic acid was 0.26. In vitro thrombolytic activity of SAET is significant with $48.51 \%$ clot lysis capability compared to that of Streptokinase (68.57\%). It can be considered for compound isolation in order to detect future anti-tumour compounds.

In vitro thrombolytic activity of SAET is significant with $48.51 \%$ clot lysis capability compared to that of Streptokinase $(68.57 \%)$. It can be considered for compound isolation in order to design future anti-tumour drug. SAET had appreciable lipid peroxidation inhibition activity (Figure 8). At a concentration of $250 \mu \mathrm{g} / \mathrm{ml}$, the $\%$ inhibition of Lipid peroxidationwas $62.89 \%$ and at

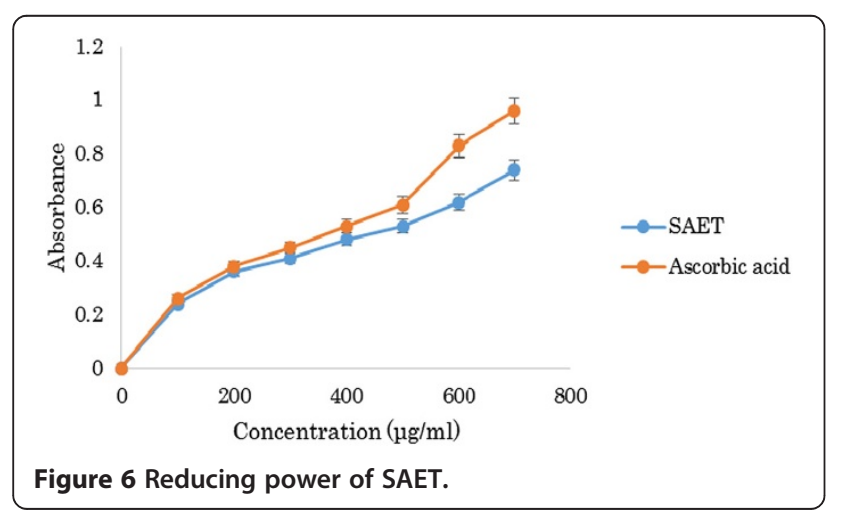

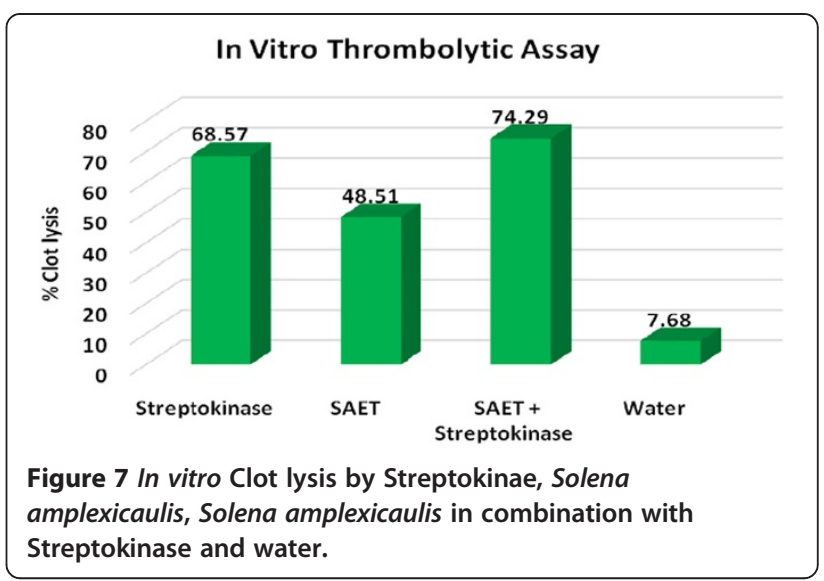

$500 \mu \mathrm{g} / \mathrm{ml}$, the \% inhibition was $78.84 \%$ while $\%$ inhibition of $\mathrm{CCl}_{4}$ and Salymarin was $49.95 \%$ and $92.77 \%$ respectively. Elevated lipid peroxidation is a common trait of cancer [32] and results suggest SAET can be used in cancer for its anti-lipid peroxidation capability and can protect cells chain reaction from breaking down due to lipid peroxidation.

Non-ligand or poorly liganded iron may be the basis of many diseases involving cell death and apoptosis [33]. Thus, the chelating ability of the extracts in regards to ferrous ions was investigated. Even though the extracts were not as strong $\mathrm{Fe}^{2+}$ chelators as EDTA, the investigated extract demonstrated notable chelating properties. Ferrous ion chelating activity of SAET was close to the results of Karthika et al. [17]. Metal chelating capacity was significant as they reduced the concentration of catalyzing transition metal in lipid peroxidation. Spot assay result provides us an indication that SAET exert protective activity to cells against stress and agents causing DNA damage may be due to different compounds it possess with antioxidant activity.

\section{Conclusions}

This study suggests that Solena amplexicaulis extract possesses some potentials in free-radical scavenging activity, cytotoxic and analgesic effect but it has low antimicrobial (antibacterial and antifungal) activity. The toxic

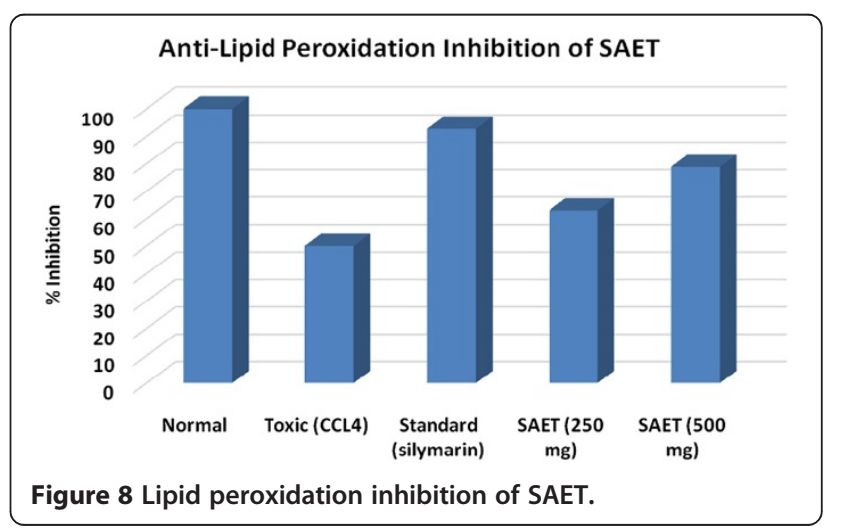


Table 8 Ferrous iron chelating assay of ethanolic root extract of Solena amplexicaulis and the standard, EDTA

\begin{tabular}{|c|c|c|c|}
\hline \multirow[t]{2}{*}{$\overline{S L}$} & \multirow{2}{*}{$\begin{array}{l}\text { Sample concentration } \\
(\mu \mathrm{g} / \mathrm{ml})\end{array}$} & \multicolumn{2}{|l|}{$\%$ inhibition } \\
\hline & & Standard EDTA & SAET \\
\hline 1 & 1000 & $53.62 \pm 0.25$ & $29.35 \pm 0.65^{*}$ \\
\hline 2 & 2000 & $68.45 \pm 0.35$ & $32.71 \pm 0.46^{*}$ \\
\hline 3 & 3000 & $79.85 \pm 0.13$ & $35.15 \pm 0.39^{*}$ \\
\hline 4 & 4000 & $89.48 \pm 0.23$ & $38.23 \pm 0.31^{*}$ \\
\hline 5 & 5000 & $94.67 \pm 0.18$ & $41.65 \pm 0.44^{*}$ \\
\hline
\end{tabular}

Values are expressed as mean $\pm S D$, *significantly different $(P<0.05)$.

nature of the alcohol extract is evident from the acute oral toxicity. Since, crude ethanol extract of Solena amplexicaulis showed antimicrobial, cytotoxic and analgesic effect, it can be assumed that different active secondary metabolites were present in this extract. These can be a strong scientific evidence to use this plant as a useful source of both biological and pharmacological references. However, further studies are necessary to elucidate the specific active compounds in the root extracts of $S$. amplexicaulis.

\section{Methods}

\section{Ethical statement}

All the experiments including animal used in this study was approved by the ethical review committee of BCSIR laboratories, Chittagong, Bangladesh.

\section{Media and chemicals}

DPPH (1, 1-diphenyl, 2-picrylhydrazyl), TCA (trichloroacetic acid) and ferric chloride, Ascorbic acid was from SD Fine Chem. Ltd. India, ammonium molybdate from Merck, Germany. Mueller-Hinton broth and agar media (Hi media, India), final $\mathrm{pH} 7.3 \pm 0.2$ (at $25^{\circ} \mathrm{C}$ ), was used for MIC determination and antibacterial. On the other hand, potato dextrose agar media ( $\mathrm{Hi}$ media, India), final $\mathrm{PH}\left(\right.$ at $\left.25^{\circ} \mathrm{C}\right) 5.6 \pm 0.2$ and artificial seawater $(3.8 \% \mathrm{NaCl}$ solution) were used for the determination of antifungal and cytotoxic effect.

\section{Table 9 Protective activity of SAET against oxidative} stress

\begin{tabular}{cc}
\hline Treatment & \% survival $^{\mathbf{a}}$ \\
\hline Untreated cells (control) & $100 \pm 1.52$ \\
$4 \mathrm{mM} \mathrm{H} \mathrm{O}_{2}$ & $26.80 \pm 0.58^{\mathrm{b}}$ \\
$\mathrm{H}_{2} \mathrm{O}_{2}+200 \mu \mathrm{g} / \mathrm{mL}$ extract & $39.17 \pm 2.08^{\mathrm{c}}$ \\
$\mathrm{H}_{2} \mathrm{O}_{2}+400 \mu \mathrm{g} / \mathrm{mL}$ extract & $65.98 \pm 1.15^{\mathrm{c}}$ \\
$\mathrm{H}_{2} \mathrm{O}_{2}+800 \mu \mathrm{g} / \mathrm{mL}$ extract & $88.66 \pm 0.58^{\mathrm{c}}$
\end{tabular}

${ }^{\mathrm{a}}$ Average $\pm \mathrm{SD} .{ }^{\mathbf{b}}$ Significantly different from the untreated cells (control) by the analysis of variance (ANOVA) and Dunnett's t-test $(p \leq 0.05)$. 'Significantly different from the stressing agents by the analysis of variance (ANOVA) and Dunnett's t-test $(p \leq 0.05)$.

\section{Collection of plant materials}

Very rare medicinal plant Solena amplexicaulis was collected from various regions of Khagrachari District of Chittagong Hill Tracts of Bangladesh. The plant was identified by Professor Dr. Md. Mostofa Kamal Pasha, Taxonomist, Department of Botany, University of Chittagong, Chittagong, Bangladesh.

\section{Extraction}

The fresh roots of Solena amplexicaulis were washed with water immediately after collection and then chopped into small pieces, air-dried at room temperature for about 10 days and pulverized into powder form and stored in an airtight container. $2 \mathrm{~kg}$ root powder was macerated in $6 \mathrm{~L}$ pure ethanol for 7 days at room temperature. After 7 days, root's ethanolic extract was filtered off through a cotton plug and finally with a Whatman No. 1 filter paper. Then the solvent retaining in the crude extract was evaporated under reduced pressure below $50^{\circ} \mathrm{C}$ through a rotary vacuum evaporator. The concentrated extracts were collected in a Petri dish and allow to air dry for complete evaporation of ethanol. The whole process was repeated two times and finally, $80 \mathrm{gm}$ concentrated Solena amplexicaulis root extract (SAET) was obtained (yield $4 \% \mathrm{w} / \mathrm{w}$ ) which was kept in refrigerator at $4^{\circ} \mathrm{C}$.

\section{Phytochemical screening}

Freshly prepared crude extracts of Solena amplexicaulis root were subjected to qualitative test for the presence of different constituents using the following reagents and chemicals, flavonoids with the use of $\mathrm{Mg}$ and $\mathrm{HCl}$; tannins with ferric chloride and potassium dichromate solutions and saponins with ability to produce stable foam and steroids with Libermann Burchard reagent, reducing sugars with Benedict's reagent and observed color change in respective [34].

\section{Determination of total phenolic content}

Folin-Ciocalteu method was used to determine the total phenolic content; Folin-Ciocalteu oxidized the extract whereas sodium carbonate neutralized it. Blue color formed and the absorbance was measured at $760 \mathrm{~nm}$ after $60 \mathrm{~min}$ by using gallic acid (GA) as standard. Total Phenolic content was expressed as mg GA equivalent/ gm of extract [35].

\section{Determination of total flavonoid content}

Method described by Meda et al. [36] was followed to determine the flavonoid content where quercetin was used as standard.

\section{Determination of total ascorbic acid (ASC)}

Total ascorbic acid (ASC) content of the extract was determined according to the method described by Roe and Kuether [37]. 


\section{Antioxidant activity}

The antioxidant activity of the extract is carried out based on the scavenging activity of the Table 1, 1 diphenyl-2 picrylhydrazyl (DPPH) according to the method described by Brand-William et al. [38].

\section{Brine shrimp lethality assay}

Cytotoxic activity of plant extract was determined by BrineShrimp lethality bioassay as previously described [39].

\section{$a$-amylase inhibition assay}

To determine the in vitro $\alpha$-amylase inhibition by ethanolic root extracts of Solena amplexicaulis, the standard procedure [40] was adopted with slight modification.

\section{Reducing power}

The reducing power of Solena amplexicaulis extract was determined according to the method of Oyaizu [41].

\section{In vitro thrombolytic activity}

Individuals from whom the blood samples were collected were informed and upon their consent they were included in this study. Samples were taken from adult healthy individual. No children were included in this study. In vitro thrombolytic activity was performed according to Ratnasooriya et al. [42].

\section{Metal chelating effect}

The chelation of ferrous ions by the extract was estimated as per the method of Dinis et al. [43].

\section{Antibacterial screening}

The in vitro sensitivity of the bacteria to the test material was done by disc diffusion technique [44] against 6 grampositive (Bacillus subtilis ATCC 11774, Staphylococcus aureus ATCC 25923, Bacillus cereus ATCC 10876, Bacillus polymyxa ATCC 842, Bacillus megaterium ATCC 13578, Enterococcus faecalis ATCC 29212) and 8 gram-negative bacteria (Salmonella typhi ATCC 12022, Klebsiella pneumonia ATCC 65154, Shigella flexneri ATCC 13883, Shigella sonnei ATCC 8992, Proteus vulgaris ATCC 13315, E. coli ATCC 25922, Vibrio cholerae ATCC 15748, Pseudomonas aeruginosa ATCC 25853). All the results were compared with the standard antibacterial drug tetracycline.

\section{Determination of Antifungal activity}

The poisoned food technique [45] was used to screen for anti-fungal activity.

\section{Minimum inhibitory concentration (MIC)}

Minimum Inhibitory Concentrations (MIC) were determined by macro dilution method [45].

\section{Spot assay}

Wild type Saccharomyces cerevisiae was used to investigate the effect of extract on the growth of yeast cells, to select the doses of extract used in the adaptive treatments. Saccharomyces cerevisiae cells $\left(\mathrm{OD}_{600}\right.$ of $\left.0.6-1\right)$ without and with exposure to increased concentrations of extract $(200,400$ and $800 \mu \mathrm{g} / \mathrm{ml})$ and stressing agent (2 $\mathrm{mM}$ ) were incubated in a YPD medium for $1 \mathrm{hr}$ at $28^{\circ} \mathrm{C} / 160 \mathrm{rpm}$. In all cases, about $3 \mu \mathrm{l}$ of yeast saturated cultures after $1 \mathrm{hr}$ incubation were serially diluted $\left(10^{-1}\right.$, $10^{-2}, 10^{-3}$ and $10^{-4}$ ), and were dropped on standard YPDA plates and Hydroxyurea $(150 \mathrm{mM})$ laden YPDA plates. Plates were incubated at $28^{\circ} \mathrm{C}$, and growth was recorded after 24, 48 and 72 hrs by counting colony. The lowest concentration was chosen which could improve cell growth compared to cohorts exposed to stress without being treated with plant extract.

\section{Experimental animals and diets}

Swiss albino mice of both sexes weighing between 25 gm and $30 \mathrm{gm}$ were taken from animal house of BCSIR laboratories, Chittagong. The animals were acclimatized to room temperature $\left(28 \pm 5^{\circ} \mathrm{C}\right)$ with a relative humidity of $55 \pm 5 \%$ in a standard wire meshed plastic cages for 4 to 5 days prior to commencement of the experiment. During the entire period of study the animals were supplied with standard pellet diet and adlibitum water.

\section{Acute toxicity}

Acute toxicity of ethanolic root extract of $S$. amplexicaulis in mice was determined according to Bulus et al. [46].

\section{Analgesic activity}

Analgesic activity was performed according to Vittalrao et al. [47].

\section{Lipid peroxidation inhibition assay}

The lipid peroxidation inhibition assay was determined according to the method described by Liu et al. [48].

\section{Antinociceptive activity}

Antinociceptive activity of the crude extract was tested using the model of acetic acid induced writhing in mice [49].

\section{Anti-inflammatory activity}

Carrageenan induced rat hind paw edema was used as the animal model of acute inflammation according to the method of Jude et al. [50].

Competing interest

The authors declare no conflict of interests. 


\section{Authors' contributions}

MGK and SI planned the research work and NUA collected the plant. MR performed extraction and antioxidant activity. RMM and MF performed the antibacterial and antifungal activity. NUA performed brine shrimp lethality assay. RMM and MF drafted the manuscript and all authors have read and approved the manuscript.

\section{Acknowledgement}

The authors were thankful to Professor Dr. Md. Mostofa Kamal Pasha, Taxonomist, Department of Botany, University of Chittagong, Chittagong, Bangladesh for the support in identification of the plants.

\section{Author details}

${ }^{1}$ Department of Biochemistry and Molecular biology, University of Chittagong, chittagong 4331, Bangladesh. ${ }^{2}$ Bangladesh Council of Scientific and Industrial Research (BCSIR) Laboratories Chittagong, Chittagong 4220, Bangladesh. ${ }^{3}$ Institute of Food Science \& Technology (IFST), Bangladesh Council of Scientific and Industrial Research (BCSIR), Dhaka 1205, Bangladesh.

Received: 25 May 2014 Accepted: 21 July 2014

Published: 19 August 2014

\section{References}

1. Wittstock U, Gershenzon J: Constitutive plant toxins and their role in defense against herbivores and pathogens. Curr Opinion Plant Biol 2002, 5(4):300-307.

2. Chung PY, Chung LY, Ngeow YF, Goh SH, Imiyabir Z: Antimicrobial activities of Malaysian plant species. Pharma Biol 2004, 42:292-300.

3. Nair R, Chanda SV: Antibacterial activity of some medicinal plants of Saurashtra region. J Cell Tissue Res 2004, 4:117-120.

4. De $\mathrm{N}$, Ifeoma $\mathrm{E}$ : Antimicrobial effects of components of the bark extracts of Neem (AzadirachtaindicaA. Juss). Technol Dev 2002, 8:23-28.

5. Ghani A: Medicinal Plants of Bangladesh: Chemical Constituents and Uses. Dhaka: Asiatic Society of Bangladesh; 1998

6. Edeoga $\mathrm{HO}$ : Phytochemical constituents of some Nigerian medicinal plants. Afr J Biotech 2005, 4(7):685-688.

7. Thomas MC: Diuretics, ACE inhibitors and NSAIDs - the triple whammy. Med J Aust 2000, 172:184-185.

8. Kritchevsky D: Fiber, lipids and atherosclerosis. Am J Clin Nut 1978, 31S:65-74.

9. Kirtikar KR, Basu BD: Indian Medicinal Plants, Volume -II. 3rd edition. 1988:1162-1163.

10. Warrier PK: Indian medicinal plants, compendium of 500 species. Orient Longman Ltd 1996, -5:173.

11. Arun CH, Kumar RS, Srinu S, Babu GL, Kumar GR, Babu JA: Anti-inflammatory activity of aqueous extract of leaves of Solena amplexicaulis. Int I Res Pharma Biomed Sci 2011, 2(4):1617-1619.

12. Venkateshwarlu E, Reddy AR, Goverdhan P, Rani KS, Reddy GJ: In vitro and in vivo antioxidant activity of methanolic extract of Solenaamplexicaulis (whole plant). Intl J Pharma Bio/ Sci 2011, 1(4):522-533.

13. Karthika K, Paulsamy S, Jamuna S: Evaluation of in vitro antioxidant potential of methanolic leaf and stem extracts of Solenaamplexicaulis (Lam.) Gandhi. J Chem Pharma Res 2012, 4(6):3254-3258.

14. Pullaiah T, Murthy KSR, Goud PSP, Kumar TDC, Vijayakumar R: Medicinal plants used by the tribals of nallamalais, eastern Ghats of India. J Trop Med Plants 2003, 4(2):237-244.

15. Rahim ZB, Rahman MM, Saha D, Hosen SMZ, Paul S, Kader S: Ethnomedicinal plants used against jaundice in bangladesh and its economical prospects. Bull Pharma Res 2012, 2(2):91-105.

16. Devi $P$, Meera R, Badmanaban $R$, Patel CN: Anti-inflammatory activity of Solena amplexicaulis. Biogeosciences 2007, 2(3):293.

17. Karthika K, Paulsamy S: Antibacterial potential of traditional plant species Solena amplexicaulis(LAM.) Gandhi. Against certain human pathogens. Asian J Pharma Clin Res 2012, 5(4):255-257.

18. Wallace RJ: Antimicrobial properties of plant secondary metabolites. Proceed Nutr Soc 2004, 63:621-629.

19. Lucy H, DaSilva EJ: Medicinal plants: A re-emerging health aid. Elect J Biotechnol 1999, 2:56-70.

20. Koduru S, Grierson DS, Afolayan AJ: Antimicrobial activity of Solanum aculeastru. Pharma Biol 2006, 44:283-286.
21. Okeke MI, Iroegbu CU, Eze EN, Okoli AS, Esimone CO: Evaluation of extracts of the root of Landolphia owerrience for antibacterial activity. J Ethnopharmacol 2001, 78:119-127.

22. Prakash O, Kumar R, Mishra A, Gupta R: Artocarpus heterophyllus (Jackfruit): an overview. Pharmacognosy Rev 2009, 3:353-358.

23. Hatano T, Edamatsu R, Hiramatsu M, Mori A, Fujita Y, Yasuhara: Effects of interaction of tannins with coexisting substances. VI. Effects of tannins and related polyphenols on superoxide anion radical and on DPPH radical. Chem Pharma Bull 1989, 37:2016-2021.

24. Fakruddin M, Mannan KSB, Mazumdar RM, Afroz H: Antibacterial, antifungal and antioxidant activities of the ethanol extract of the stem bark of Clausena heptaphylla. BMC Complement Alt Med 2012, 12:232.

25. Sunita B, Mahendra R: Antifungal activity of essential oils from Indian medicinal plants against human pathogenic Aspergillus fumigatus and A. Niger. World J Med Sci 2008, 3(2):81-88.

26. Reichart JA, Daughters RS, Simone DA: Peripheral and preemptive opiodantinociception, in a mouse visceral pain model. Pain 2001, 89:221-227.

27. Ronaldo AR, Mariana LV, Sara MT, Adriana BPP, Steve SH, Fernando QC: Involvement of resident macrophages and mast cells in the writhing nociceptive response induced by zymosan and acetic acid in mice. Eur $J$ Pharmacol 2000, 387:111-118.

28. Hira A, Dey SK, Howlader MSI, Ahmed A, Hossain H, Jahan IA: Anti-inflammatory and antioxidant activities of ethanolic extract of aerial parts of Vernonia patula (Dryand.) Merr. Asian Pac J Trop Biomed 2013, 3(10):798-805.

29. Laboni FR, Akhter M, Batul UK: Evaluation of antinociceptive and antioxidant properties of theEthanolic extract of tino sporacordifolia stem from Bangladesh. Pharmacol Online 2013, 3:88-94.

30. Bhandari MR, Jong Anurakkun N, Hong G, Kawabata J: a-Glucosidase and a-amylase inhibitory activities of Nepalese medicinal herb Pakhanbhed (Bergenia ciliata, Haw.). Food Chem 2008, 106(1):247-252

31. Jung M, Park M, Lee HC, Kan YH, Kang ES, Kim SK: Antidiabetic agents from medicinal plants. Curr Med Chem 2006, 13(10):1203-1218.

32. Klauning JE, XU Y, Isenberg JS, Bachowski S, Kolaja KL, Jianga J, Stevenson DE, Waloorg EF Jr: The role of oxidative stress in chemical carcinogenesis. Envir Heal Persp 1998, 106:289-333.

33. Kell DB: Towards a unifying, systems biology understanding of large-scale cellular death and destruction caused by poorly liganded iron: Parkinson's, Huntington's, Alzheimer's, prions, bactericides, chemical toxicology and others as examples. Arch Toxicol 2010, 84:825-889.

34. Ghani A: Medicinal plants of Bangladesh with chemical constituents and uses. 2nd edition. Bangladesh: Asiatic Society of Bangladesh; 2003:1-16.

35. Singelton VR, Orthifer R, Lamuela- Raventos RM: Analysis of total phenols and other oxidation substrates and antioxidants by means of Folin-Ciocalteu reagent. Meth Enzymol 1999, 299:152-178.

36. Meda A, Lamien CE, Romito M, Millogo J, Nacoulma OG: Determination of the total phenolic, flavonoid and proline contents in burkina fasan honey, as well as their radical scavenging activity. Food Chem 2005, 91:571-577

37. Roe $\mathrm{JH}$, Kuether CA: The determination of ascorbic acid in whole blood and urine through the 2, 4-dinitrophenylhydrazine derivatives of dihydroascorbic acid. J Biol Chem 1943, 147:399-407.

38. Brand-Williams W, Cuvelier ME, Berset C: Use of a free radical method to evaluate antioxidant activity. Food Sci Technol 1995, 28:25-30.

39. Meyer BN, Ferrigni NR, Putnam JE, Jacobsen LB, Nichols DE, McLaughlin JL: Brine Shrimp: A convenient general bioassay for active plant constituents. Planta Med 1982, 45:31-34.

40. Hashim A, Khan MS, Khan MS, Baig MH, Ahmad S: Antioxidant and a-amylase inhibitory property of Phyllanthus virgatus L.: an In Vitro and molecular interaction study. BioMed Res Int/ 2013, 729393. Article ID.

41. Oyaizu M: Studies on product of browning reaction prepared from glucose amine. Jpn J Nutr 1986, 44:307-315

42. Ratnasooriya WD, Fernando TSP, Madubashini PP: In vitro thrombolyticactivity of Sri Lankan black tea, Camellia sinensis (L.) O Kuntze. J Natn Sci Foundation Sri Lanka 2008, 36(2):179-181.

43. Dinis TCP, Madeira VMC, Almeida LM: Action of phenolic derivates (acetoaminophen, salicylate, and 5-aminosalicylate) as inhibitors of membrane lipid peroxidation and as peroxyl radical scavengers. Arch Biochem Biophy 1994, 315:161-169.

44. Bauer AW, Kirby WM, Sherris JC, Turck M: Antibiotic susceptibility testing by a standardized single disk method. Am J Clin Pathol 1966, 45:493-496 
45. Saha A, Rahman MS: Antimicrobial activity of crude extract from calycopteris floribunsa. Bang J Microbiol 2008, 25:137-139.

46. Bulus T, Atawodi SE, Mamman M: Acute toxicity effect of the aqueous extract of terminalia avicennioides on white albino rats. Sci World J 2011, 6(2):1-4.

47. Vittalrao AM, Shanbhag T, Meena KK, Bairy KL, Smita S: Evaluation of antiinflammatory and analgesic activities of alcoholic extract of kaempferia galanga in rats. Ind J Physiol Pharmacol 2011, 55(1):13-24.

48. Liu F, Nagaki TB: Antioxidative and free radical scavenging activities of selected medicinal herbs. J Life Sci 2000, 66:725-735.

49. Ahmed F, Selim MST, Das AK, Choudhuri MSK: Anti-inflammatory and antinociceptive activities of Lipia nodiflora Linn. Pharmazie 2004, 59:329-330

50. Jude EO, Anwanga EU, Samuel GF, Louis UA: Anti-inflammatory and analgesic activities of Melanthera scandens. Asian Pac J Trop Biomed 2012, 2(2):144-148.

doi:10.1186/0717-6287-47-36

Cite this article as: Kabir et al: Antioxidant, antimicrobial, toxicity and analgesic properties of ethanol extract of Solena amplexicaulis root.

Biological Research 2014 47:36.

\section{Submit your next manuscript to BioMed Central and take full advantage of:}

- Convenient online submission

- Thorough peer review

- No space constraints or color figure charges

- Immediate publication on acceptance

- Inclusion in PubMed, CAS, Scopus and Google Scholar

- Research which is freely available for redistribution 